\title{
Grapevine Cultivars, Trellis Systems, and Mechanization of the California Raisin Industry
}

\author{
Matthew W. Fidelibus ${ }^{1}$
}

AdDitional INDEX wORDs. continuous tray, dry-on-vine, DOV, grape, Vitis vinifera

SummaRy. Growers in California's San Joaquin Valley produced $>\mathbf{2 5 \%}$ of the world's raisins in 2012, with a farm-gate value of $>\$ 590$ million, making the United States the leading global producer of raisins. California's traditional raisin-making method is a laborious process in which clusters of grapes (Vitis vinifera) are harvested by hand onto paper trays, which are left in the vineyard to dry. The drying fruit may need to be turned or rolled, tasks requiring manual labor, and the trays of dried raisins are also picked up by hand. Most California raisins continue to be made in this way, but in recent years, the declining availability and increasing cost of labor has prompted many growers to implement one of two mechanized production systems, "continuous tray" (CT) or "dry-on-vine" (DOV). In CT systems, machines are used to pick the berries, lay them onto a tray, and pick up the dried raisins. The CT system could be considered a short-term strategy: it is compatible with existing conventional 'Thompson Seedless' raisin vineyards and has been widely adopted. The DOV system could be considered a medium-term strategy: it is best suited for vineyards specifically designed for DOV, with early ripening grapevine cultivars on expansive trellis systems, which ensures timely drying, and capitalizes on the fact that sunlit row middles are not needed for fruit drying. Grapevine breeding programs are currently working toward the development of raisin grape cultivars with fruitful basal nodes, with fruit that dry naturally upon ripening. This is a long-term strategy to further reduce labor needs by enabling mechanical pruning in winter and eliminating the need for cane severance in the summer.

\section{History}

The California raisin industry was established in 1873 , following the development of adequate irrigation and transportation systems, and the introduction and distribution of appropriate grapevine cultivars (Christensen, 2000a; Meyer, 1931). The earliest raisin crops were produced in northern California, near Davis, but the southcentral San Joaquin Valley has a warmer and drier climate than the northern valley and is thus better-suited for making natural sun-dried raisins. Thus, the U.S. raisin industry soon became concentrated within a 30 -mile radius of Fresno, CA (Christensen, 2000a;

Department of Viticulture and Enology, University of California, One Shields Avenue, Davis, CA 95616

This paper was part of the colloquium "Strategy for Developing Mechanical Harvesting of Horticultural Crops: Simultaneous Short-, Medium-, and Longterm Strategies" held 24 July 2013 at the ASHS Annual Conference, Palm Desert, California, and sponsored by the Production and Harvest Mechanization $(\mathrm{MECH})$ Working Group

Many of the research projects referenced in this manuscript were supported by the California Raisin Marketing Board. Inspiration, guidance, and support from the late L.P. Christensen are gratefully acknowledged. I also thank T.V. da Costa and S. Van Zyl for reviewing an earlier version of this manuscript.

${ }^{1}$ Corresponding author. E-mail: mwfidelibus@ucdavis. edu.
Meyer, 1931; Quaschnick, 2002). By 1904, the United States had surpassed Spain as the leading global producer of raisins (Meyer, 1931). The land area planted to raisin grapes in California peaked in 1983 at $\approx 272,000$ acres and has declined most years since then (Fig. 1). Poor prices and high labor costs initiated vineyard pullouts that continued even after prices improved due, in part, to potentially better returns from other commodities, especially nut crops (Lapsley, 2011), and continuing labor shortages (Calvin and Martin, 2010b). Despite the declines in planted area, CA remains the largest global raisin producer, accounting for $\approx 30 \%$ of world production in recent years [U.S. Department of Agriculture (USDA), 2013].

\section{Grapevine cultivars used}

California's first raisins were made from 'Muscat of Alexandria', a traditional European raisin grape that has relatively large, seeded, berries and a muscat flavor. California muscat raisins were initially sold as wholecluster "layers," but the development of deseeding machines and other processing technologies led to the marketing of loose, high quality, seedless raisins in cartons (Meyer, 1931). 'Thompson Seedless', a naturally seedless neutral-flavored grape, became available in 1875 (Shields, 2002), and growers soon realized it was a superior raisin grape. Even so, it did not supersede 'Muscat of Alexandria' until 1922 (Shear and Gould, 1927), partly because prohibition had eliminated wine as a potential alternative market for 'Muscat of Alexandria' (Quaschnick, 2002). Since then, 'Thompson Seedless' has retained its status as the dominant raisin cultivar in California, accounting for $90 \%$ of the 200,000 acres of raisin-type grapes in California [California Department of Food and Agriculture (CDFA) and USDA, 2013]. However, a combination of technological advances and economic/ social changes now favor the adoption of mechanized raisin-making practices (Calvin and Martin 2010b), which, in California's climate, require cultivars that ripen earlier than 'Thompson Seedless'.

The development of early ripening raisin grapes has long been an important goal of the Horticultural Crops Research Laboratory, USDA Agricultural Research Service, which has maintained a grape breeding program in Fresno County, CA, since 1923 (Ramming, 2002). Early ripening allows drying to begin earlier, thus reducing the risk of rain damage that increases as the drying season progresses; eventually, it was recognized that earliness also enabled the production of DOV raisins (Ramming, 2002). 'Fiesta', which typically ripens about 1 week earlier than 'Thompson Seedless', was the first raisin cultivar released from this program (Weinberger and Loomis, 1974). Between 1995 and 2001, four other early ripening raisin grapes cultivars were released, including

\begin{tabular}{llll}
\hline $\begin{array}{l}\text { Units } \\
\begin{array}{l}\text { To convert U.S. to SI, } \\
\text { multiply by }\end{array}\end{array}$ & U.S. unit & SI unit & $\begin{array}{l}\text { To convert SI to U.S., } \\
\text { multiply by }\end{array}$ \\
\hline 0.4047 & acre(s) & ha & 2.4711 \\
0.3048 & $\mathrm{ft}$ & $\mathrm{m}$ & 3.2808 \\
1.6093 & mile(s) & $\mathrm{km}$ & 0.6214
\end{tabular}


Selma Pete, which ripens about 3 weeks earlier than Thompson Seedless (Fidelibus et al., 2008). These early ripening cultivars are gradually beginning to replace 'Thompson Seedless'. Of the $\approx 9000$ acres of "Thompson type" raisin grapes planted in California between 2006 and 2012, "Thompson Seedless' only accounted for $\approx 34 \%$, with the newer, earlier-ripening cultivars Fiesta and Selma Pete accounting for $25 \%$ and $40 \%$, respectively (CDFA and USDA, 2013). Thus, most new California raisin vineyards are not being planted with 'Thompson Seedless'.

\section{Traditional drying methods}

California's traditional raisinmaking method involves harvesting clusters of ripe (soluble solids $\geq 20 \%$ ) grapes by hand and spreading them, one-cluster deep, onto $2 \times 3$ - $\mathrm{ft}$ trays, which are left on the vineyard floor to dry. Trays were initially wooden, which enabled them to be stacked to provide rain protection and unstacked after the threat of rain. However, wooden trays required expensive maintenance, handling was laborious, and their bulk required considerable storage space (Christensen and Peacock, 2000a). Thus, in the early 20th century, wood trays were gradually replaced with sheets of paper having the same dimensions as the wooden trays and also retaining the term "tray" (Reddemann, 1924). The shift to paper trays helped reduce labor needs, but conventional tray-dried raisin making remained among the most laborious agricultural processes in North America (Calvin and Martin, 2010a). After picking, additional labor may be needed to invert (turn) the fruit on the trays, particularly if clusters are particularly bulky, the trays have been overfilled, or drying conditions are suboptimal (Christensen and Peacock, 2000b). Near the end of the 2- to 3-week drying process, labor crews return to the vineyards to roll the trays, a process that prevents over drying, allows raisins of different moistures to equilibrate, and facilitates pickup of the trays. Finally, when the raisins have dried to an acceptable moisture content of $9 \%$ to $16 \%$, crews return once again to collect the raisin trays, depositing the raisins in bins.

Until 2000, nearly all of California's raisins were made using traditional traydrying methods (Fig. 2), requiring up to 44,000 farm workers to accomplish all

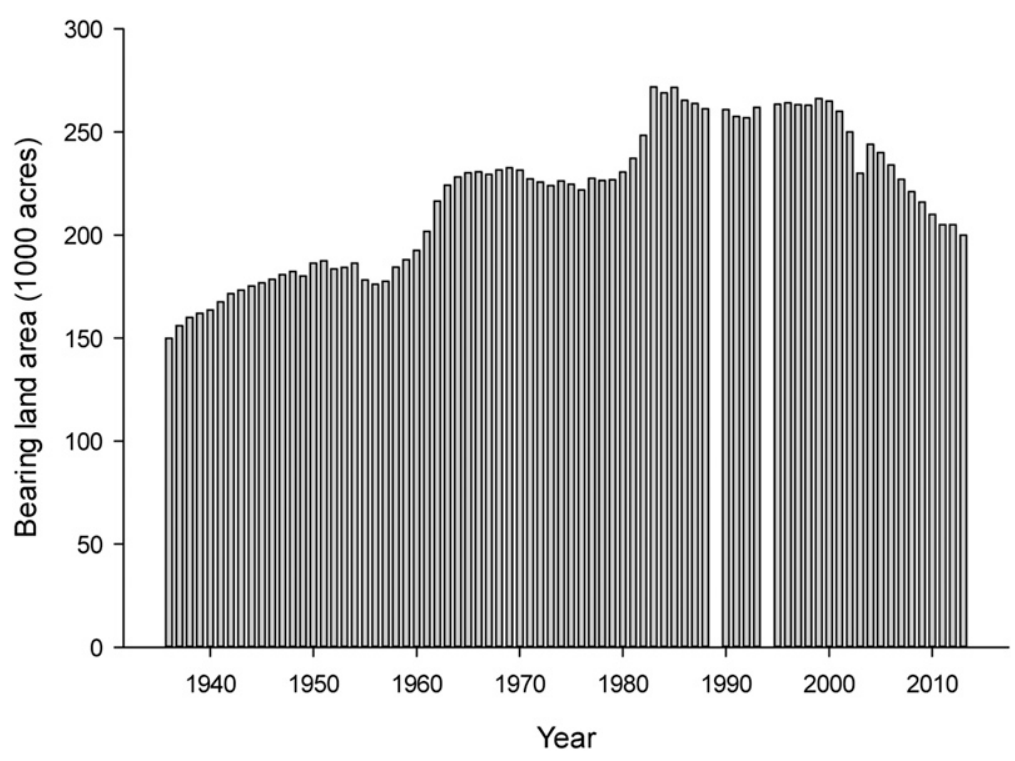

Fig. 1. Land area in California with bearing raisin grapes, 1936 to 2013 ; 1 acre = 0.4047 ha.

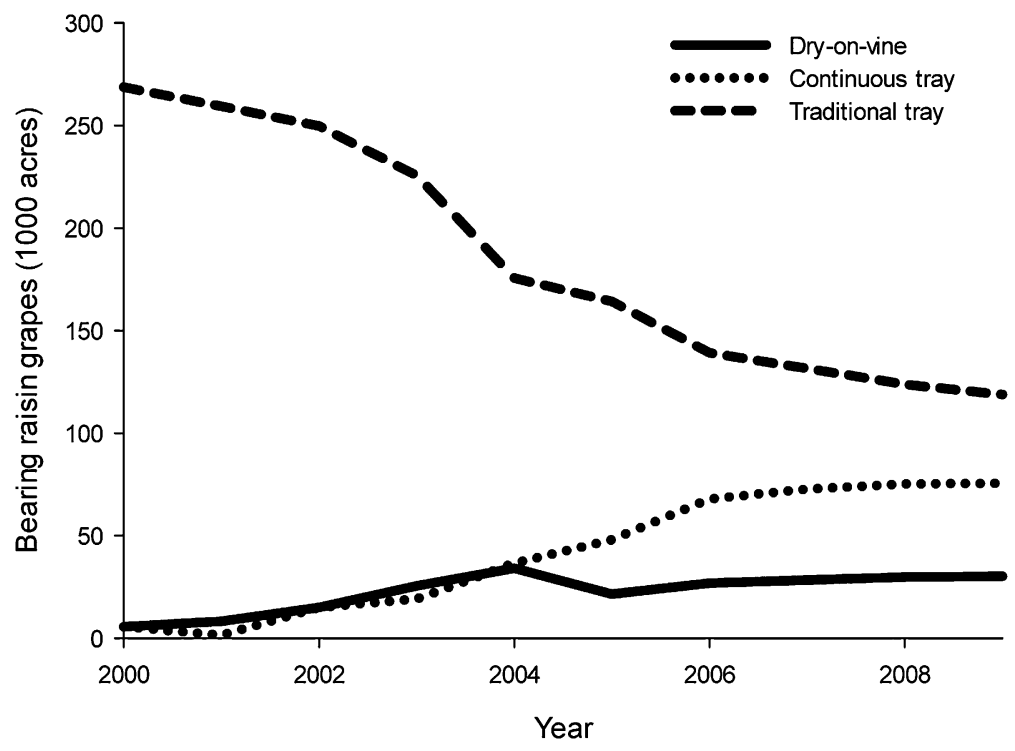

Fig. 2. Land area in California with dry-on-vine, continuous tray, and traditional tray raisin production systems. Values are based on annual raisin grape acreage from the U.S. Department of Agriculture multiplied by estimated annual adoption of continuous tray and dry-on-vine provided by R. Brase (California AgQuest Consulting, Fresno, CA); 1 acre $=0.4047$ ha.

of these tasks in the 4- to 6-week harvest window (Calvin and Martin, 2010a). Recognizing that such massive labor requirements would eventually become financially and socially unsustainable, researchers from USDA, University of California (UC), California State University Fresno, and innovative growers worked for decades, collaboratively and independently, to develop and refine mechanization technologies. Early efforts focused on minimizing the labor associated with tray drying. Mechanized fruit removal was an obvious goal, but existing grape harvesters, which were designed for juice and wine grapes, can impart excessive mechanical damage to grapes, rendering them unsuitable for raisin making (Fidelibus et al., 2007a).

\section{Continuous tray}

In 1965, Studer and Olmo made the chance discovery that severing the 
fruit-bearing canes of 'Thompson Seedless' causes the rachises to dry and become brittle within $\approx 1$ week, and subsequent shaking of the vines caused the clusters to shatter, detaching the berries with their pedicels, or "cap stems," attached, thereby preventing stem-end tearing, a common type of mechanical damage in machineharvested fruit (Studer, 2000; Studer and Olmo, 1974). This discovery enabled the development of the socalled "continuous-tray" method, in which raisin growers sever the fruitbearing canes to dry the rachises, and then $\approx 1$ week later, mechanically harvest the partially dried grapes into hoppers from which they are spread onto a length of paper known as a CT (Christensen, 2000b). Individual berries are deposited onto a tray in a single layer, which allows them to dry faster than they would if attached to whole clusters. Thus, turning and rolling are not needed, and a pick-up machine is used to collect the dried raisins from the trays.

The CT method requires fewer laborers than traditional tray drying and can reduce production cost (Vasquez et al., 2007). However, the capital cost of this system on a land area basis is relatively high (Studer, 2000), and with sufficient labor and acceptable raisin prices, the economic incentive for widespread adoption was lacking. In fact, only one grower, E. Rocca, regularly used the CT for the first 30 years after its introduction. It was not until 2002 , following a $56 \%$ drop in raisin prices and a tightening labor market, that other growers began to rapidly adopt this technique, which has now become the industry's most widely implemented mechanized harvest technology (Fig. 2) (Calvin and Martin, 2010b).

The sudden widespread implementation of the CT production method resulted in some technological challenges, including cases of excessive mechanical damage due to poorly executed cane severance. Abscission agents were investigated as a potential alternative to cane severance, and some compounds that loosened the attachment of berries to their pedicels and promoted the development of dry stem scars were identified (Fidelibus et al., 2007a). However, consistent loosening required the application of a relatively large amount of chemicals, and fruit drop begins within a few days of application (Gonzalez-Herranz et al., 2009). Thus, excessive chemical residues, cost, and yield loss are all potential concerns that would need to be overcome if abscission agents are ever to be commercially adopted as harvest aids.

\section{Dry-on-vine}

Continuous tray has become the most widely accepted mechanized raisin production method in California because of its compatibility with existing conventional raisin vineyards (Fig. 2). However, newer raisin vineyards are typically developed with the intention of implementing a different mechanized production method, DOV. Dry-on-vine, like CT, is not a particularly new idea. Australians began experimenting with cane severance to initiate vine-drying of 'Sultana' (synonym 'Thompson Seedless') raisin grapes in Australia beginning in 1958 (May and Kerridge, 1967). Following cane severance, the grapes are left on the trellises to dry, so DOV vineyards do not require sunlit drying areas between the rows, as tray-dry systems do. Therefore, DOV vineyards may use larger, more expansive trellises that greatly increase yield potential (Fidelibus et al., 2008). However, the drying process proceeds much more slowly on trellises than on trays because temperatures in the canopy are lower than those at the soil surface (Christensen and Peacock, 2000b). To hasten drying, the Australians apply an alkaline drying emulsion, a practice that also helps preserve the light color typical of 'Sultana' raisins (Clingeleffer, 2011). However, drying emulsion is not widely used in California because a darker colored "natural" raisin is preferred. Without drying emulsion, 'Thompson Seedless' is poorly suited for DOV because it ripens too late in the season to dry adequately (Fidelibus et al., 2007b). Therefore, natural "Thompson type" DOV raisins were not widely produced in California until after the year 2000, when both appropriate plant material and economic incentive were present.

Two types of DOV systems are widely used in CA; overhead arbor and open gable. Overhead arbor systems were mainly developed by two growers: L. Simpson and G. Pitts. Simpson developed a high-density overhead arbor vineyard in 1991 with head-trained and cane-pruned 'Fiesta' grapevines, and Pitts developed a similar system using vines that are more widely spaced and trained to quadrilateral cordons (Christensen, 2000 b). In both systems, the vine's canopies are separated into fruiting and renewal sections by pruning the vines and tying their canes in such a way that trellis wires spanning the spaces between adjacent rows support either fruiting canes or renewal shoots (Fig. 3). By midsummer, vine canopies may entirely cover the vineyard surface area, enabling yields that are 2 to 2.5 times higher than that of conventional raisin vineyards (M.W. Fidelibus, unpublished data). When the fruit have amassed $>20 \%$ soluble solids, canes are severed near their base, initiating the DOV process. Fruit generally dry into raisins within 6 to 8 weeks, at which time the raisins are harvested from the trellises with a special low-profile machine (Fig. 4). Various harvest machines for this system have been developed by growers and agricultural equipment companies, and a single machine may harvest about 15 acres per day.

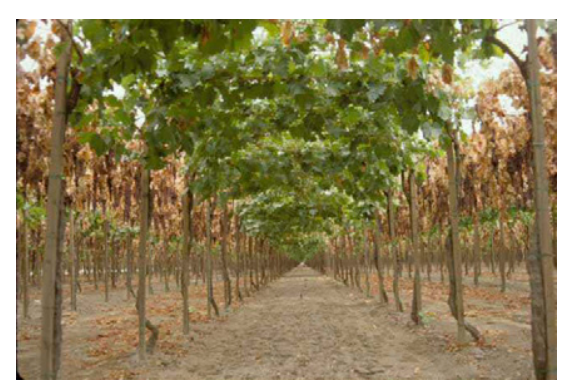

Fig. 3. An overhead arbor dry-on-vine raisin grape production system showing how coordinated pruning and tying of canes separates the vine's canopies into alternating renewal (center) and fruiting (either side) sections.

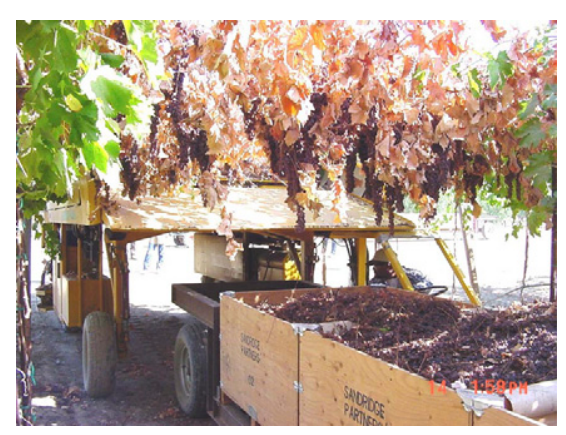

Fig. 4. Harvesting dry-on-vine raisin grapes from an overhead arbor trellis. 
The open gable system was developed at UC by L.P. Christensen in the 1990s (Christensen, 2000b; Fidelibus et al., 2008). The open gable system uses a large Y-shaped trellis, similar to that commonly used by table grape growers in California. Vines may be head or cordon trained, and cane pruned. Fruiting canes are tied to the lower two of three foliage catch wires on either trellis cross arm and, in the spring, rake wires are used to pull renewal shoots toward a single foliage catch wire in the center of the trellis, thus separating the canopy into fruiting and renewal zones. Canes are severed as with the overhead

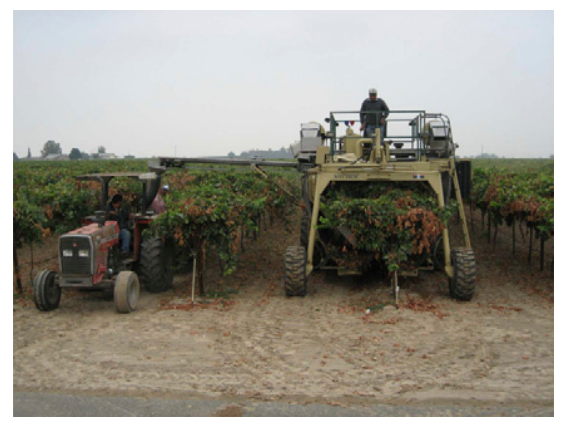

Fig. 5. Harvesting dry-on-vine raisin grapes from an open gable trellis.

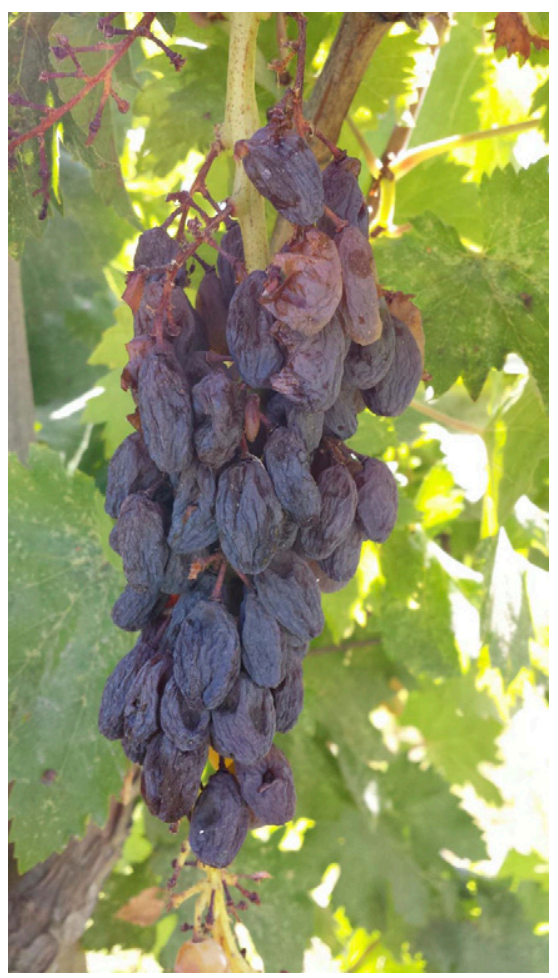

Fig. 6. An unreleased sport of 'Selma Pete' raisin grape whose fruit spontaneously dries after ripening. arbor and, usually, a large over-the-row grape harvester is used to harvest the dried raisins, directly from the trellis (Fig. 5). A single harvest machine can typically harvest $\approx 15$ acres of raisin grapes on open gable trellises in one day, and yields are typically 1.75 to 2.25 times greater than those of a conventional raisin vineyard (Fidelibus et al., 2008). Presently, overhead arbor and open gable DOV systems together account for $\approx 12 \%$ of production, but it is anticipated that DOV will eventually replace traditional and CT systems due to the combined benefits of reduced labor and increased productivity (Calvin and Martin, 2010b).

The introduction of new grapevine cultivars and production systems often raises questions about quality and consumer acceptance, and these questions should be addressed before widespread commercialization (Angulo et al., 2007; Christensen et al., 1983). For example, 'Selma Pete' grapes are more acidic than 'Fiesta', and thus make raisins which are more sour tasting (Angulo et al., 2007; Parpinello et al., 2012). Dry-on-vine raisins also have finer wrinkles than tray-dried raisins, and grapevine cultivar and drying method can interact to affect many flavor, texture, and appearance attributes of raisins (Angulo et al., 2007). However, average consumer hedonic test scores of 'Fiesta' and 'Selma Pete' raisins, and tray-dry and DOV production methods were similar (Angulo et al., 2007).

\section{Breeding efforts to produce grapes that spontaneously DOV}

The berries of certain grape cultivars and selections can spontaneously DOV, without the need for cane severance (Aung et al., 2002; Ramming, 2002). 'Diamond Muscat' and 'Selma Pete' have this tendency (Fig. 6), but in most years, the spontaneous drying process begins too late and proceeds too slowly to result in adequate drying, so the canes of those cultivars still need to be cut as soon as their berries have amassed an adequate amount of soluble solids (Fidelibus, personal observation). However, USDA has made considerable progress toward breeding a "natural" DOV cultivar that does not need cane severance to initiate drying. The release of such a cultivar could have profound effects on grapevine management and productivity since the timing of cane severance strongly affects raisin yield and quality (Parpinello et al., 2012), and optimal trellis and vineyard designs may be different from those currently used for DOV raisins. A spontaneous DOV cultivar should also further reduce labor needs, especially if it had fruitful basal nodes, and could thus be easily pruned mechanically.

\section{Conclusions}

California has been a leading global producer of raisins for more than a century. However, raisins are a labor-intensive crop, and farm labor is no longer inexpensive or plentiful in California. Therefore, domestic raisin growers will increasingly need to adopt mechanized production practices. Dry-on-vine raisin cropping systems that simultaneously minimize labor needs and maximize yield potential are likely to displace tray-dried production practices, and the land area planted to raisin grapes may continue to decrease as production per unit area of land increases.

\section{Literature cited}

Angulo, A., M.W. Fidelibus, and H. Heymann. 2007. Grape cultivar and drying method affect sensory characteristics and consumer preference of raisins. J. Sci. Food Agr. 87:865-870.

Aung, L.H., D.W. Ramming, and R. Tarailo. 2002. Changes in moisture, dry matter and soluble sugars of dry-on-thevine raisins with special reference to sorbitol. J. Hort. Sci. Biotechnol. 77: 100-105.

California Department of Food and Agriculture and U.S. Department of Agriculture. 2013. California grape acreage report, 2012 summary. California Dept. Food Agr., U.S. Dept. Agr., Sacramento, CA.

Calvin, L. and P. Martin. 2010a. Immigration reform: What does it mean for agriculture and rural America? Appl. Econ. Perspectives Policy 32:232-253.

Calvin, L. and P. Martin. 2010b. Laborintensive U.S. fruit and vegetable industry competes in a global market. Amber Waves 8:24-32.

Christensen, L.P. 2000a. Background and resources, p. 3-8. In: L.P. Christensen (ed.). Raisin production manual. Univ. California, Agr. Natural Resources, Oakland, CA. 
Christensen, L.P. 2000b. Current developments in harvest mechanization and DOV, p. 252-263. In: L.P. Christensen (ed.). Raisin production manual. Univ. California, Agr. Natural Resources, Oakland, CA.

Christensen, L.P. and W.L. Peacock. 2000a. Harvesting and handling, p. 193-206. In: L.P. Christensen (ed.). Raisin production manual. Univ. California, Agr. Natural Resources, Oakland, CA.

Christensen, L.P. and W.L. Peacock. $2000 \mathrm{~b}$. The raisin drying process, p. 207-216. In: L.P. Christensen (ed.). Raisin production manual. Univ. California, Agr. Natural Resources, Oakland, CA.

Christensen, P., D. Ramming, and H. Andris. 1983. Seed trace content of Fiesta grapes. Amer. J. Enol. Viticult. 34: 257-259.

Clingeleffer, P. 2011. Mechanization of grape production in Australian vineyards, p. 111-120. In: J.R. Morris and P.L. Brady (eds.). Vineyard mechanization: Development and status in the United States and in major grape producing regions of the world. ASHS Press, Alexandria, VA.

Fidelibus, M.W., K.A. Cathline, and J.K. Burns. 2007a. Potential abscission agents for raisin, table, and wine grapes. HortScience 42:1626-1630.

Fidelibus, M.W., L.P. Christensen, D.G. Katayama, and D.W. Ramming. 2008. Early-ripening grapevine cultivars for dry-on-vine raisins on an open-gable trellis. HortTechnology 18:740-745.

Fidelibus, M.W., S.J. Vasquez, and K.A. Cathline. 2007b. Canopy separation and defoliation do not improve the dry-onvine (DOV) raisin-making method for 'Thompson Seedless' grapevines on traditional trellises. J. Amer. Pomol. Soc. 61:61-70.

Gonzalez-Herranz, R., K.A. Cathline, M.W. Fidelibus, and J.K. Burns. 2009. Potential of methyl jasmonate as a harvest aid for 'Thompson Seedless' grapes: Concentration and time needed for consistent berry loosening. HortScience 44:13301333.

Lapsley, J. 2011. Winegrapes and nuts: Historical review of production in the San Joaquin Valley and implications for the future. 14 Nov. 2013. <http://aic.ucdavis. edu/publications/FutureWinegrapesSan Joaquin.pdf/>.

May, P. and G.H. Kerridge. 1967. Harvest pruning of Sultana vines. Vitis 6:390-393.

Meyer, E.C. 1931. The development of the raisin industry in Fresno County, California. Univ. California, Davis, MS Thesis.

Parpinello, G.P., H. Heymann, S. Vasquez, K.A. Cathline, and M.W. Fidelibus. 2012. Grape maturity, yield, quality, sensory properties, and consumer acceptance of Fiesta and Selma Pete dry-on-vine raisins. Amer. J. Enol. Viticult. 63:212-219.

Quaschnick, L. 2002. The history of the California raisin industry, p. 39-60. In: V.E. Petrucci and C.D. Clary (eds.). A treatise on raisin production, processing, and marketing. Malcolm Media Press, Clovis, CA.

Ramming, D.W. 2002. Methods of developing improved raisin cultivars, p. 85-98. In: V.E. Petrucci and C.D. Clary (eds.). A treatise on raisin production, processing, and marketing. Malcolm Media Press, Clovis, CA.

Reddemann, O.A. 1924. Raisin drying tray. Patent US1492392 A. U.S. Patent Trademark Office, Washington, DC.

Shear, S.W. and H.F. Gould. 1927. Economic status of the grape industry. California Agr. Expt. Sta. Bul. 429.

Shields, A. 2002. A lust for the Lady de Coverly, p. 48-60. In: V.E. Petrucci and C.D. Clary (eds.). A treatise on raisin production, processing, and marketing. Malcolm Media Press, Clovis, CA.

Studer, H.E. 2000. Raisin harvest mechanization: A bit of history, p. 245-251: In: L.P. Christensen (ed.). Raisin production manual. Univ. California, Agr. Natural Resources, Oakland.

Studer, H.E. and H.P. Olmo. 1974. Parameters affecting the quality of machine harvested raisins. Trans. Amer. Soc. Agr. Eng. 17:783-786.

U.S. Department of Agriculture. 2013. Raisins: World markets and trade. U.S. Dept. Agr., Foreign Agr. Serv. Circ. Ser. September 2013.

Vasquez, S.J., M.W. Fidelibus, L.P. Christensen, W.L. Peacock, K.M. Klonsky, and R.L. De Moura. 2007. Sample costs to produce raisins - Continuous tray-harvest equipment purchased used and refurbished, San Joaquin Valley. Univ. California Coop. Ext., Dept. Agr. Resource Econ., Davis.

Weinberger, J.H. and N.H. Loomis. 1974. 'Fiesta' grape. HortScience 9:603. 